(RESEARCH ARTICLE)

\title{
Potential and feasibility of ecotourism at Sorong Nature Tourism Park
}

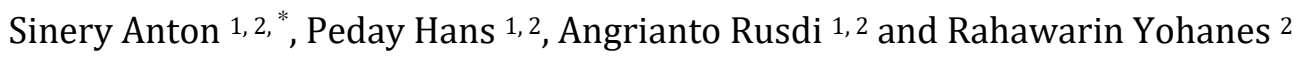 \\ ${ }^{1}$ Forestry Faculty, Papua University Jl. Gunung Salju Amban Manokwari, 98314. \\ ${ }^{2}$ Research Center for Environmental Scince at University of Papua, Jl Gunung Salju Amban Manokwari, 98313 phone: \\ 085244308802.
}

Publication history: Received on 20 May 2020; revised on 01 June 2020; accepted on 09 June 2020

Article DOI: https://doi.org/10.30574/wjarr.2020.6.3.0163

\begin{abstract}
The aim of the research was to determine the potential of the Sorong nature tourism park (NTP), potential feasibility and management startegis of area.That potential consisting of the biophysical conditions of the area (climate, topography, geology, soil and hydrology in the form of rivers and waterfalls) as well as biodiversity potential both flora (flora natural forest and plantation forest) and fauna and management by the unit institution. The area was feasible to be developed as ecotourism with a feasibility index of $84.09 \%$.
\end{abstract}

Keywords: Potential; Ecotourism; Nature Tourism Park; Sorong

\section{Introduction}

Papua Barat, like the other provinces, was one of the regions that was striving to intensify development in order to realize the welfare of the community while still being a sustainable development. One of the efforts was carried out by maintaining 70\% of protected areas in accordance with article 7 paragraph 2 point b.5 PP 13 of 2017 concerning national spatial planning and the commitment of the government and community of West Papua Province through sustainable development. To realize this intention, the regional government and all related parties continue to make efforts to optimize the function of protected area functions through the revision of Regional Regulation No. 4 of 2013 concerning the 2013-2033 RTRW (spatial planning) of West Papua Province with the present achievement percentage of $57 \%$ of the target of $70 \%$ (draft revised of RTRW 2013-2033). According to [1] Papua Barat West Papua currently had $39 \%$ of marine protected areas, which when combined with land areas could contribute 55-60\% of protected areas according to the draft revised of Papua Barat spatital planning 2013-2033 of and the draft of SEA (strategies environment assessment of Papua Barat spatial planning 2013-2033).

Sorong Regency with an area of $13,603.46 \mathrm{Km}^{2}$ had a variety of interesting tourism objects and had the potential to be developed as tourist objects and attractions. One of them was the Sorong NTP area which was one of the nature conservation areas based on Minister of Agriculture Decree No. 397 / KPTS / UM / 5/1981 as a land conservation area in Sorong city with an area of approximately 945.90 ha [2] and through Minister of Forestry Regulation No. P.02 / Menhut-II / 2007 management authority was transferred from the Sub-Office of Protection and Nature Conservation to the West Papua Natural Resources Conservation Office.

Sorong NTP as a forest area that had an attractive landscape had the potential to be used as a tourist destination. However, this area had not been used optimally, both the use of tourism space, tourist facilities and community engagement that had not been optimal. For this reason, it was necessary to conduct research to determine the potential and feasibility of managing this area as a potential and tourist attraction.

\footnotetext{
${ }^{*}$ Corresponding author: Sinery Anton
} 


\section{Material and methods}

This research was conducted in the Sorong NTP area at Km 14 of Klasaman villages, East Sorong District, Sorong City, West Papua Province and lasted for two months (September - October 2019). The method used was a descriptive method with interview and survey techniques with respondents that included community respondents (managers) and visitor respondents (general). Determination of community respondents, especially in Klasaman as the closest village to the area using the equation according to Slovin (1960) in [3], namely:

$$
n=\frac{\mathrm{N}}{1+\mathrm{N}(\mathrm{e})^{2}}
$$

Information:

$\mathrm{n}=$ number of samples, $\mathrm{N}=$ total population, $\mathrm{e}=10 \%$ error limit, $1=$ constant number

The population in the study site (Km14) was 81 people, so the number of respondents determined was 45 people. Retrieval of visitor respondents was conducted purposively of visitors who entered this area. The number of visitor respondents was 25 respondents. Data from observations and interviews were further analyzed descriptively and presented in tables and figures. The potential of objects and attractions were analyzed according to the score criteria accordance to the guidelines for the analysis of the area of operation of objects and natural attraction by director general of protected forest natural conservation (PFNC/PHKA 2003). Components assessed were attraction of tourism objects, accessibility, conditions of the socioeconomic environment, accommodation, facilities and supporting infrastructure, availability of clean water, safety and comfort. Scores for one ecotourism (ODTWA) assessment criteria could be calculated by the following equation:

$$
\mathrm{S}=\mathrm{N} \times \mathrm{B}
$$

Information:

$\mathrm{S}=$ score / value of a criterion, $\mathrm{N}=$ Number of values of elements in the criterion, $\mathrm{B}=$ Weight value

The results of the subsequent analysis were compared with the total score of a criterion if each sub-criterion had a maximum value. Determination of the percentage of eligibility of each criterion was known through simple calculations with the equation [4].

$$
\text { Feasibility of tourism objects }(\%)=\frac{S_{\text {total }}}{S_{\text {maximum }}} \times 100
$$

Information:

Stotal $=$ Total score of a criterion, Smaximum $=$ maximum score for each criterion

After comparison, a feasibility index would be obtained in percent [4], as shown in Table 1.

Table 1 Classification of Development Elements Based on Weight Weights for Each Assessment

\begin{tabular}{llll}
\hline No & Total eligibility value & Clasification & Rating of potential elements \\
\hline 1 & $>66,6 \%$ & Good & Feasible \\
2 & $33,3-66,6 \%$ & Medium & Feasible enough \\
3 & $<33,3 \%$ & Bad & Not feasible \\
\hline
\end{tabular}




\section{Results and discussion}

\subsection{Potential}

Sorong NTP was located at an altitude of 3 meters above sea level with a minimum air temperature of $23.2^{\circ} \mathrm{C}$ and a maximum of $32.6^{\circ} \mathrm{C}$ and $2,911 \mathrm{~mm}$ of rainfall. Rainfall was quite evenly distributed throughout the year, there was no month without rain. The number of rainy days every month between $12-27$ days, the average humidity recorded $87 \%$. This area had an area in the form of low-lying areas with altitudes ranging from 20-110 m above sea level. The lowest area was in the west, especially Klablim village towards the north and the highest area in the eastern part of the region. Slope was predominantly flat (54.98\%) and the rest was a bumpy sloping area (45.02\%) with geological potential composed of Klasaman formations and soil types of Aquaents, Aquaepts, Hemits covering 315.6 Ha and Udults, Udepts, Aquts covering $630.3 \mathrm{Ha}$. Regional water sources other than rainwater were also from 4 tributaries that flow in the west and east of this region, specifically the Klawulu river, Klasege river, Pletok river, and Kalabeling river, all of which were included in the Remu Sorong river basin.

Spread of flora in Sorong NTP area, there were 2 (two) vegetation structures, namely vegetation forest plantations and natural forest vegetation structures. In the plantation forest, the utilization block was dominated by Agathis sp plants which were arranged neatly enough to be developed as a nursery for conservation, educational research and support for cultivation.

In natural forests, the components of vegetation structure were quite diverse and there were 57 species of vegetation dominated by Intsia spp with the highest important value index (20.85\%), Agathis spp (18.07\%), Vatica spp (12.86\%), Pometia pinnata (10.59), while others Canarium spp, Callophyllum spp, Pometia pinnata., Anisoptera spp, Horea sangol., Melaleuca leucadendron has important value index of less 10\%.Pole level vegetation of 23 species and dominated by Intsia spp, Agathis spp, Vatica spp, Pometia pinnata, Canarium spp, Callophyllum spp, Melaleuca leucadendron., Anisoptera spp, Horea sangol, Artocarpus Integer. 20 species of saplings vegetation and dominated by Pometia pinnata, Canarium spp, Callophyllum spp, Agathis spp, Vatica spp, Intsia spp, Dracontomelon edule, Psidium guajava, Podocarpus blumeii, Diospyross spp. Seedling-level vegetation consisted of 24 predominant species Pometia pinnata, Canarium spp, Callophyllum spp, Agathis spp, Vatica spp, Podocarpus blumeii, Diospyross spp, Pericopsis moonisma, Lansium domesticum, Alstonia spp [5].

Data on the potential of fauna / animals identified by the Papua Barat conservation nature resource of fice (BBKSDA) based on tropic level was inhabited by mammal classes, there were 13 species, 51 species aves, 16 species of reptiles, and 3 species of amphibia. There were potential fauna / animals that were protected species for the class of mammals were Spilocuscus maculatus and Phalanger orientalis. Species of protected species were Meliphaga aruensis, Philemon buceroides, Taxorhampus novaeguineae, Halcyon macleayi, Melidora macrorrhina, Loriius lory, Eclectus roratus, Cacatua galerita, Rhyticeros plicatus. Furthermore, endemic species such as Acipiter fasciatus, A. novaeholandeae, Rhyticerus licatus, Melanocmaris nigra, Oriolus zalayi, Paradiseae minor. Species of reptiles that were protected were Varanus sp, and Morelia viridis. Then the species of endemic amphibia was Platymantis papuensis[5].

The characteristics of the natural scenery in the Sorong NTP area were found in and around the area in the form of natural and artificial landscapes. The characteristics of natural tourism potential in the west to south of the area along $\mathrm{Km} 14$ to $\mathrm{Km} 18$ in the form of artificial landscap in the form of crocodile breeding, agricultural land, ornamental plant sales areas, stadiums, campuses, border monuments and government operational buildings such as government offices and military posts. While around the area was a view of community gardens, rivers and natural forests. The characteristics of natural tourism potential in the form of natural landscapes further illustrated the natural scenery in the area, with the main character being the formation of lowland tropical rain forest types that were still intact.

The potential of a waterfall with a cliff height of 5 meters with a volume of water and the speed of the current was not so heavy, with a good diversity of vegetation both flora and fauna that had not been disturbed. Beautiful natural panorama, beautiful and comfortable natural atmosphere created new nuances for visitors so that it could add value to the products and or tourist attractions that could be offered. There were 4 rivers that cross the Klawulu river, Klasege river, Pletok river and Klabeling river. The river originated from a spring and becomes a potential water provider for life in the area. The speed of the water flow in the river was not too heavy so that it was used by visitors when traveling.

Bird watching was an activity of observing birds and their behavior in nature. The existence of birds in the Sorong NTP area could add value to the tourism potential because it could attract the interest of visitors, especially those who were happy with bird watching, education, research or just want to see and hear their voices. [6] stated that one of the reasons 
for supporting an interesting area to visit was if the area had attractions that could be used, for example wildlife that was interesting or unique to a particular place.

Bird watching was usually done in the morning and evening because at that time the birds usually moved so that they could be found. In general, the presence of birds in the Sorong NTP area was seen in the morning and evening. Based on interviews with regional officials it was known that bird watching activities were carried out in the morning at 07.00 09.00 Central Indonesian Time, then in the afternoon at 16.00 - 18.00 Central Indonesian Time.

Forest plants in the Sorong NTP area had secondary forest stands of Agathis labilardieri species that had the potential to be developed as seed source stands. Issue of development of Agathis sp. took place since 2006 and had conducted several surveys. TWA Sorong already had a certificate of forest damar type plant seeds (Agathis labillardieri) No. ST. 53 / BPTH.MP-2 / SERT.SB / 2012 Date 31 May 2012 Seed source number 92.71.001 covering 36.50 Ha by Maluku and Papua Forest Plant Seeding Center (BPTH).

It was expected that with the establishment of certified seed source stands from the Maluku and Papua BPTH, the function of the area would be to support cultivation outside the area, including alternative economic empowerment for the surrounding community, and an increase in the number of tourist attractions that could be enjoyed by visitors with the aim of education, research and recreation

\subsection{Evaluation of natural tourism object and attraction assessment}

Table 2 Results of appraisal components of attraction

\begin{tabular}{lllll}
\hline No & Elements / Sub elements & Rate & Value & Score \\
\hline 1 & The uniqueness of natural resources & 6 & 25 & 150 \\
2 & The number of natural resources was prominent & 6 & 30 & 180 \\
3 & Nature tourism activities that could be done & 6 & 25 & 150 \\
4 & Cleanliness of the tourism location & 6 & 25 & 150 \\
5 & Regional security & 6 & 30 & 180 \\
6 & Convenience & 6 & 30 & 180 \\
\hline Total & & 165 & 990 \\
\hline
\end{tabular}

The attractiveness of an area was the main thing that makes the area attractive for tourists to visit and did tourist activities. The Sorong NTP area had the potential to be strong enough to attract tourists to visit this area. The value of the Sorong NTP attraction criteria was high with a very good variety of attractiveness elements. The natural beauty of Sorong NTP was shown by the existence of several places to look at other views from a distance, the atmosphere that was presented in the object, the composition of the attraction and environmental conditions of the object. The types of natural tourism activities that could be carried out were very diverse, namely enjoying the beauty of nature, tracking, camping, bird watching, flora observation, spiritual tourism, cross-country, Hunting / Photography and others. The uniqueness of natural resources in the Sorong NTP region was the typical species of flora and fauna. Flora, fauna and water were the potential natural resources that stand out in this region. The security of the Sorong NTP area was quite good because there was no illegal logging, fires and other disturbances.

Table 3 Results of the accessibility assessment

\begin{tabular}{|c|c|c|c|c|}
\hline No & Elements / Sub elements & Rate & Value & Score \\
\hline 1 & Road condition & 5 & 30 & 150 \\
\hline 2 & Distance & 5 & 30 & 150 \\
\hline 3 & Road type & 5 & 30 & 150 \\
\hline 4 & Travel time from the city center & 5 & 30 & 150 \\
\hline \multicolumn{2}{|c|}{ Total } & & 120 & 600 \\
\hline
\end{tabular}


High accessibility would increase the development of an object of tourist attraction and the availability of many and diverse means of transportation guaranteeing safety greatly helps smooth travel of tourists [7]. The condition of the road to the Sorong NTP area was very good with the type of asphalt road with a width of $3 \mathrm{~m}$ and quite close to the city center (14 Km / 30 minutes travel time) using 2-wheeled or 4-wheeled vehicles. The situation illustrated the situation of the tourist sites in Sorong NTP very easily to access. According [7] that one of the factors that made an area attractive to visitors was its location that was closed, close enough or far from the international airport or the main tourist center or city center and also travel to the region was easy and comfortable, it was necessary minimal effort, difficult or dangerous.

Table 4 Results of Accommodation Assessment Around the Area

\begin{tabular}{lllll}
\hline No & Elements / Sub elements & Rate & Value & Score \\
\hline 1 & Lodgings Number & 3 & 20 & 60 \\
2 & Rooms Number of rooms & 3 & 30 & 90 \\
\hline \multicolumn{2}{l}{ Total } & & 50 & 150 \\
\hline
\end{tabular}

The availability of accommodation in a tourist location was an important factor for visitors who want to stay at the location. According to [7] that accommodation was one of the factors that made visitors interested in making a tourist visit. The accommodation appraisal was located around an area with a radius of $15 \mathrm{~km}$ from attractions, from the assessment there were a number of hotels and inns which number more than 30 inns with a number of rooms more than 100, one of the hotels closest to the Sorong NTP area was The Luxio hotel. Accommodation around the Sorong NTP area was very adequate, this was because the location of the tourist attraction was close to downtown Sorong or Sorong Regency so that access to the location was very easy and the availability of complete accommodation facilities in the city.

Table 5 Results of management, care and service assessment to visitors

\begin{tabular}{lllll}
\hline No & Elements / Sub elements & Rate & Value & Score \\
\hline 1 & Management organization stability & & & \\
& Management Status & 4 & 20 & 80 \\
& Number of Employees & 4 & 10 & 40 \\
& Lowest employee income & 4 & 10 & 40 \\
& Budget funds & 4 & 15 & 60 \\
& Source of funds & 4 & 15 & 60 \\
& Employee Status & 4 & 20 & 80 \\
& Change of leadership & 4 & 20 & 80 \\
3 & Quality of service & 4 & 20 & 80 \\
4 & Language ability & 4 & 10 & 40 \\
\hline Total & & 4 & 20 & 80 \\
\hline
\end{tabular}

This factor must be improved in the utilization of natural attractions, because it was related to visitor satisfaction and object preservation. The weakest institution was the area manager or tour guides, if these two parties advance, nature tourism would develop [7]. The score obtained was 160. It shown that the management and service conditions for visitors to Sorong NTP were very good, so the score was very high, where the status of tourism management was carried out by the Papua Barat conservation of natural resources office with 5 field officers and more than $50 \%$ as permanent employees. Changes in leadership for the past 5 years were 1 time, and budget funds included administration, maintenance, development and operational funds. Quality of service consisted staff friendliness, excellent communication skills. As well as maintenance facilities and services such as rest areas, parking areas, and toilets were 
well maintained. Management and service of visitors was important so that it was improved, because it directly affects visitor satisfaction and the preservation of the object itself.

Table 6 Results of the assessment of climate conditions

\begin{tabular}{lllll}
\hline No & Elements / Sub elements & Rate & Value & Score \\
\hline 1 & The influence of climate on visit times & 4 & 10 & 40 \\
2 & Air temperature $\left({ }^{\circ} \mathrm{C}\right)$ & 4 & 30 & 120 \\
3 & Number of dry and humid months on average per year (month) & 4 & 10 & 40 \\
4 & Average solar radiation (\%) during the rainy season & 4 & 15 & 60 \\
5 & Season's wind speed & 4 & 20 & 80 \\
6 & The average moist temperature per year & 4 & 5 & 20 \\
\hline Total & & & 90 & 360 \\
\hline
\end{tabular}

Climate change in terms of supply was predicted to cause damage to natural and cultural resources which were the main products of tourism. Climate change from the demand side, would affect tourist visiting patterns and tourist perceptions and preferences [8]. Climatic conditions in Sorong NTP as generally the island of Papua were classified as moderate, due to the geographical area below the equator making this region a wet tropical climate with relatively stable average temperatures. Based on climatic data from 2013-2019 from meteorology, climatology and geophysic agency of Sorong, it was known that the average air temperature of this region was $27^{\circ} \mathrm{C}$ and the average monthly humidity was around 89\% which generally was very supportive for tourism activities. According to [9], the range of comfortable outside air temperatures for humans was 21-27으 C. According to [10], ideal air humidity for human comfort in order to be able to carry out their activities properly was in the range of $40-75 \%$.

Table 7 Results of the assessment of supporting facilities and infrastructure

\begin{tabular}{lllll}
\hline No & Elements / Sub elements & Rate & Value & Score \\
\hline 1 & Utilities & 3 & 50 & 150 \\
2 & Infrastructure & 3 & 50 & 150 \\
\hline Total & & & 100 & 300 \\
\hline
\end{tabular}

Facilities and infrastructures in the tourist area were one of the important attraction factors in the management of ecotourism, this influences and influences the progress of a tourist attraction. Supporting infrastructure that was built by the area manager including the entrance gate, area signage, warning board, guard post / information center, area entrance post (entrance ticket), shelter, camping ground, gazzebo, toilet, footpath, interpretation path, pond swimming and entertainment stage including plans to build a bird watching tower. Supporting infrastructure available within a 10 $\mathrm{km}$ radius included a post office, health center, and the presence of a telephone network, electricity and drinking water network. Supporting facilities were also very adequate such as the availability of restaurants, shopping centers, banks, and souvenir shops located in the nearest market also got a value of 50 . Facilities and infrastructure around the Sorong NTP area were very adequate because of the location of the area not far from the city center.

Table 8 Assessment results of the availability of clean water

\begin{tabular}{lllll}
\hline No & Elements / Sub elements & Rate & Value & Score \\
\hline 1 & Volume of water & 6 & 65 & 390 \\
2 & Whether water could be flowed to an object or easily sent from & 6 & 30 & 180 \\
& another place & 6 & & \\
3 & Consumed Feasibility & 6 & 15 & 90 \\
$4 \quad$ Continuity & 6 & 15 & 90 \\
\hline Total & & 125 & 750 \\
\hline
\end{tabular}


The availability of clean water was an important factor in the development of a tourism object both for tourism management and services. According to [11] in conducting ecotourism activities the availability of clean water in the form of fresh water was very necessary to support the management facilities and ecotourism services, therefore it became a criterion for evaluating the feasibility of developing ecotourism priorities. The availability of clean water in the area was very supportive with a value of 750 for the development of natural tourism in the region. The volume of water in the Sorong NTP was considered sufficient because the water was available throughout the year and never dries during the dry season. Water from existing water sources was easily flowed to the location of tourism objects in Sorong NTP, but it needs to develop pipeline facilities.

Table 9 Promotion ratings and market potential

\begin{tabular}{lllll}
\hline No & Elements / Sub elements & Rate & Value & Score \\
\hline 1 & Rates / Prices & 4 & 10 & 40 \\
2 & Tourism Products / variations & 4 & 10 & 40 \\
3 & Information Submission and & 4 & 15 & 60 \\
4 & Promotion & 4 & 15 & 60 \\
\hline \multicolumn{2}{l}{ Total } & & 50 & 200 \\
\hline
\end{tabular}

Marketing tourism in the area of natural tourism parks with rates or prices that were applied in the affordable category with a variety of products obtained by visitors to the means of delivering information and promotions had also been done including through social media (Facebook, Instagram) and through newspapers and TV. Sorong NTP had various natural tourist attraction objects, but there was no entry into force of the area for the visitors. It was planned that the intended tariff would be carried out if it had been carried out properly. Promotional activities had been carried out both by the Papua Barat natural resources conservation office as well as some nature-loving communities and also visitors who come to this area by promoting the existence of Sorong NTP through exhibitions, leaflet distribution, promotion in newspapers, and promotion on social networks via the internet, Facebook, Instagram etc. [4] stated that to develop regions that had not yet potential to become potential areas as tourist attraction objects, promotion and marketing efforts were needed to attract market potential.

Table 10 Results of the assessment of community's social economic conditions

\begin{tabular}{lllll}
\hline No & Elements / Sub elements & Rate & Value & Score \\
\hline $\mathbf{1}$ & Land use / planning & 5 & 15 & 75 \\
$\mathbf{2}$ & Land ownership status & 5 & 20 & 100 \\
$\mathbf{3}$ & Livelihood of the population & 5 & 20 & 100 \\
$\mathbf{4}$ & Level of education & 5 & 20 & 100 \\
$\mathbf{5}$ & Public perception of the development of natural attractions & 5 & 20 & 100 \\
\hline Total & & 95 & 475 \\
\hline
\end{tabular}

The development of tourism objects in an area needs to involve the participation of the community as part of (customary owners), even residents who lived around the area. Therefore, community support was very important in the management of attractions. The results of the evaluation of the socio-economic conditions of the community around the Sorong TWA area strongly support the status of the area as state forest due to the existing legal status (Decree of the Minister of Agriculture Number: 397 / Kpts / Um / 5/1981) and managed by the Papua Barat natural resources conservation office (BBKSDA). The Sorong NTP spatial plan already exists but was not in accordance with the conditions of potential objects and tourist attractions. Most of the people living around the area had graduated from high school and worked as farmers. So expect the development of Sorong NTP would open up business opportunities and create new jobs so that it could increase income and welfare of the community. Communities around the area were very supportive of efforts to develop ecotourism in Sorong NTP.

In general, each criterion had a different value and overall affects the eligibility index, as shown in the following table. 
Table 11 Recapitulation of tourism feasibility criteria evalution

\begin{tabular}{llllllll}
\hline No & Criteria & Rate & Value & Score & $\begin{array}{l}\text { Score } \\
\text { max }\end{array}$ & $\begin{array}{l}\text { Feasibility } \\
\text { Index (\%) }\end{array}$ & Classification \\
\hline 1 & Daya Tarik & 6 & 165 & 990 & 1080 & 91.67 & High \\
2 & Accessibility & 5 & 120 & 600 & 600 & 100.00 & High \\
3 & Accomodation & 3 & 50 & 150 & 180 & 83.33 & High \\
4 & Services to visitors & 4 & 160 & 640 & 360 & 77.7 & High \\
5 & Climatic conditions & 4 & 90 & 360 & 480 & 75.00 & Medium \\
6 & Facilities and infrastructure & 3 & 100 & 300 & 300 & 100.00 & High \\
7 & Clean water availability & 6 & 125 & 750 & 900 & 83.33 & High \\
8 & Promotion and marketing & 4 & 50 & 200 & 120 & 66.67 & Medium \\
9 & Community Social Economic & 5 & 95 & 475 & 600 & 79.17 & Medium \\
\hline Total & & & 4,465 & & 756,87 & \\
\hline \multicolumn{2}{l}{ Average } & & & & 84,09 & \\
\hline
\end{tabular}

The highest value was in the accessibility and supporting infrastructure facilities with a feasibility index value (100\%), followed by an attraction factor (91.67\%), then the lowest value was in the promotion and marketing elements $(66.67 \%)$. High classified elements need to be optimized in the management of the area even elements that were categorized as being targeted to be addressed to improve management effectiveness.

\section{Conclusion}

Potential natural tourism attractions in Sorong NTP included the biophysical conditions of the region such as climate, topography, geology and soil as well as hydrology as well as biodiversity potential in the form of flora and fauna. Based on the evaluation results of the assessment of natural tourist attraction objects in this region deserved to be developed as ecotourism with a feasibility index of $84.09 \%$.

\section{Compliance with ethical standards}

\section{Acknowledgments}

The authors are thankful for communty in Klasaman, Papua Barat Conservation Natural Resource Office (BBKSDA) and center of invironmental research of Papua University for assisting and contribution during field data collection. A special thanks is also extended to Yos Walianggen (M.Sc student) who have contributed to the research.

\section{Disclosure of conflict of interest}

The authors declare no conflicts of interest regarding the publication of this paper.

\section{References}

[1] Sinery AS, Burwos H, Worabay M, Jowey RN and Setiawan B.(2020). Mammals diversity in the Nutmeg Plantation area at Teluk Wondama and Teluk Bintuni Regency in West Papua Province, Indonesia. World Journal of Advanced Research and Reviews, 05(01), 079-085.

[2] Fonataba.(2018). Management Strategies for Sorong Natural Tourism Park, Papua Barat Province. Dissertation of Forestry Doctoral Mulawarman University, Samarinda

[3] Sinery AS. (2015). Management Strategies of Cuscus at Numfor Island. Deepublish, Yogyakarta. 
[4] Karsudi, Soekmadi and Kartodihardjo H. (2010). Ecotourism Development Strategies in Yapen Islands Regency of Papua Province, Tropical Forest Management Journal, XVI (3), 148-154.

[5] Fonataba Y, Aipassa MI, Simarangkir BDAS, Sumaryono MJ, Manusawai VF and Sinery AS. (2018). Community Participation in the Management of Sorong Nature Tourism Park, Sorong City. Energy and Environment Research, 8(1), 48-55.

[6] MacKinnon J, Phillipps K and Balen BV. (2010). Bird of Sumatera, Jawa, Bali and Kalimantan. LIPI-Burung Indonesia, Bogor

[7] Fandeli C.(2000). Basic Understanding and Concept of Ecotourism: Ecotourism Exploitation. Gajah Mada University. Pelajar Offset. Yogyakarta

[8] Suwarto T. (2011). The Influence of Climate and Its Changes on Coastal Destinations. Journal of Regional and City Planning, 22(1), 17-32.

[9] Robinette GO.(1983). Landscape Planning for Energy Conservation. Van Nostrand Reinhold Company, New York.

[10] Laurie M. (1986). Landscape Architecture Amsterdam and London.

[11] Handayawati.(2010). Potential of Natural Ecotourism Pantai Bahari PM PSLP PPUSB Culture and Tourism Ministry of Indonesia.

\section{How to cite this article}

Sinery A, Peday H, Angrianto R and Rahawarin Y. (2020). Potential and feasibility of ecotourism at Sorong Nature Tourism Park. World Journal of Advanced Research and Reviews, 6(3), 69-77. 